\title{
JAMBURA
}

Journal homepage: http://ejurnal.ung.ac.id/index.php/edubiosfer

\section{IDENTIFIKASI MIKROALGA EPILITIK SEBAGAI BIOMONITORING LINGKUNGAN PERAIRAN SUNGAI BULANGO PROVINSI GORONTALO}

\section{Syam S. Kumaji ${ }^{1}$, Abubakar Sidik Katili ${ }^{2}$, Pinangsi Lalu ${ }^{3}$}

1 Program Studi Biologi Fakultas Matematika dan Ilmu Pengetahuan Alam Universitas Negeri Gorontalo , Jl. Jenderal Sudirman No. 6, 96128.

${ }^{2}$ Program Studi Biologi Fakultas Matematika dan Ilmu Pengetahuan Alam Universitas Negeri Gorontalo , Jl. Jenderal Sudirman No. 6, 96128

${ }^{3}$ Program Studi Biologi Fakultas Matematika dan Ilmu Pengetahuan Alam Universitas Negeri Gorontalo , $J l$. Jenderal Sudirman No. 6, 96128.

\begin{abstract}
ABSTRAK
Penelitian ini bertujuan untuk mengetahui mikroalga epilitik sebagai bioindikator perairan sungai Bulango. Penelitian ini adalah penelitian deskriptif menggunakan metode survey. Sampel yang ditemukan diidentifikasi dengan menggunakan kunci identifikasi dan data dianalisis menggunakan analisis deskriptif. Berdasarkan hasil penelitian diperoleh bahwa pada perairan sungai Bulango ditemukan 5 mikroalga epilitik, yaitu Oscillatoria sp, Melosira sp, Oedogonium sp, Navicula sp, dan Gonium sp.
\end{abstract}

Kata Kunci : biomonitoring, mikroalga epilitik, sungai Bulango

\section{Pendahuluan}

Sungai merupakan ekosistem yang memiliki peran penting bagi semua makhluk hidup. Keberadaan ekosistem sungai dapat memberikan manfaat bagi makhluk hidup, baik yang hidup di dalam sungai maupun yang ada di sekitarnya. Menurut Soewarno (1991), sungai merupakan torehan di permukaan bumi yang merupakan penampung dan penyaluran alamiah aliran air dan material yang dibawanya dari bagian hulu ke bagian hilir suatu daerah pengaliran ke tempat yang lebih rendah dan akhirnya bermuara ke laut.

Sungai Bulango merupakan salah satu sungai yang berada di Gorontalo yang memiliki panjang 181,679 km. Sungai Bulango mencakup 1 (satu) sungai utama yang berada di Kecamatan Tapa dan 3 (tiga) anak sungai yang masing-masing melewati Kecamatan Tapa, Kecamatan Telaga, dan Kota Gorontalo. Sungai Bulango ini memiliki nilai penting bagi kehidupan masyarakat Gorontalo khususnya masyarakat Bone Bulango yang berfungsi sebagai area konservasi yang dikelola untuk mempertahankan kondisi lingkungan daerah sungai agar tidak terdegradasi. Sungai Bulango telah mengalami sedimentasi akibat berbagai kegiatan seperti padatnya pemukiman, dan meningkatnya pertanian. Penggunaan pestisida sebagai pengendali hama dalam dunia pertanian akan menghasilkan limbah yang berdampak pada perubahan kualitas perairan sungai Bulango. 
Perubahan kualitas perairan dapat dilakukan dengan menggunakan teknik biomonitoring. Menurut Zhou et al. (2008), biomonitoring merupakan teknik evaluasi lingkungan berdasarkan analisis pada jaringan dan molekul organisme yang terpapar logam berat. Selanjutnya menurut Ayeni et al. (2010) mendefisikan biomonitoring sebagai spesies-spesies yang dapat memberikan informasi terkait dengan status pencemaran lingkungan oleh polutan tertentu. Biomonitoring adalah suatu rangkaian proses evaluasi kualitas perairan dengan cara mengukur keberadan polutan tertentu pada matriks lingkungan maupun di dalam kompartemen tubuh organisme tertentu yang dapat memberikan informasi tentang status/kualitas suatu lingkungan.

Mikroalga epilitik merupakan mikroalga yang dapat tumbuh dan melekat pada berbagai substrat seperti batu, karang, kerikil dan benda keras lainnya. Sebagian besar fitoplankton adalah anggota alga hijau yang memiliki pigmen klorofil yang berperan dalam proses fotosintesis sehingga alga hijau merupakan produsen primer dalam ekosistem perairan. Menurut Adriansyah dkk, (2014) bahwa keberadaan mikroalga epilitik di perairan sungai dapat berfungsi sebagai indikator biologis untuk kualitas air, karena kemampuannya yang dapat melakukan fotosintesis dan dapat menghasilkan oksigen dalam perairan.

\section{Metodologi}

\section{Lokasi dan Waktu Penelitian}

Penelitian dilakukan di bagian hulu Desa Dulamayo Selatan, bagian tengah Desa Loangalo dan bagian hilir Desa Boidu yang berada di Sungai Bulango Kabupaten Bone Bulango. Proses identifikasi morfologi mikroalga dilaksanakan di Laboratorium Mikrobiologi, Fakultas Matematika dan IPA, Universitas Negeri Gorontalo. Penelitian ini akan dilaksanakan selama 2 bulan, yakni Januari - Februari 2018 mulai dari tahap persiapan sampai penyusunan laporan akhir.

\section{Metode}

Metode yang digunakan pada penelitian ini metode survey yaitu dengan mengambil sampel mikroalga epilitik di batu sungai yang terendam, kemudian diamati di bawah mikroskop selanjutnya diidentifikasi karakteristik morfologi dan ciri-ciri fisik mikroalga di laboratorium mikrobiologi dengan menggunakan buku identifikasi karangan karangan Serediak \& Mailinh (2011).

\section{Alat dan Bahan}

Alat yang digunakan adalah saringan teh, loyang kecil, botol plastik, sikat besar, DO meter, pengukur salinitas air, keping secchi, bola pimpong, mikroskop, kaca obyek, kaca penutup, pipet tetes, kamera, stopwatch, serta alat tulis menulis. Bahan yang digunakan yaitu: Tisu, kertas $\mathrm{pH}$, aquades.

\section{Prosedur Penelitian}

Pengambilan sampel mikroalga epilitik dilakukan pada 3 stasiun yaitu stasiun I di bagian hulu Desa Dulamayo Selatan, stasiun II di bagian tengah Desa Loangalo, dan stasiun III di bagian hilir Desa Boidu, Sungai Bulango yang berada di Kabupaten Bone Bolango dengan waktu pengambilan pada pagi hari. Untuk pengambilan sampel dilakukan dengan cara mengambil sampel dari batu yang terendam di pinggiran sungai secara acak di tiga stasiun bagian hulu Desa Dulamayo Selatan, tengah Desa Loangalo, dan hilir Desa Boidu,. Batu tersebut disikat dengan menggunakan sikat halus dengan hati-hati dan langsung diletakkan di sebuah wadah (loyang plastik) yang diberi aquadest. Kemudian disaring dengan menggunakan saringan teh dan hasil saring tersebut disimpan dalam botol plastik dan dibawah ke laboratorium mikrobiologi untuk diamati dan diidentifikasi dengan merujuk pada 
buku "Alga identification Lab Guide" karangan Serediak \& Mailinh (2011). Selain itu dilakukan pengukuran parameter fisik dan kimia sungai meliputi pengukuran suhu, $\mathrm{pH}$, salinitas air, kekeruhan, DO, kecerahan air, dan dan kecepatan arus sungai.

\section{Hasil Dan Pembahasan}

Berdasarkan hasil penelitian yang dilakukan, mikroalga epilitik yang ditemukan pada sungai Bulango didapatkan hasil seperti tertera pada Tabel 1.

Tabel 1. Mikroalga Epilitik yang Ditemukan Pada Sungai Bulango

\begin{tabular}{lllllll}
\hline No & Kelas & Ordo & Famili & Genus & Spesies & Stasiun \\
\hline 1. & $\begin{array}{l}\text { Cynaphyce } \\
\text { ae }\end{array}$ & Oscillatoriales & Oscillatoriaceae & Oscilatoria & Oscilatoria sp & I, II \\
\hline 2. & $\begin{array}{l}\text { Bacillariop } \\
\text { hyceae }\end{array}$ & Centrales & Melosiraceace & Melosira & Melosira sp & I, II, III \\
\cline { 3 - 6 } & Pennales & Naviculaceae & Navicula & Navicula $s p$ & I, II, III \\
\hline 3. & $\begin{array}{l}\text { Chlorophy } \\
\text { ceae }\end{array}$ & Oedogoniales & Oedoniaceae & $\begin{array}{l}\text { Oedogoniu } \\
\text { m Oedogonium } s p\end{array}$ & I, II \\
\cline { 2 - 6 } & Volvocales & Goniaceae & Gonium & Gonium $s p$ & I \\
\hline
\end{tabular}

Hasil pengukuran untuk parameter fisika-kimia Sungai Bulango pada masing-masing Stasiun dapat dilihat pada Tabel 2.

Tabel 2. Data Parameter Fisika-Kimia Sungai Bulango Pada Masing-masing stasiun

\begin{tabular}{|c|c|c|c|c|}
\hline \multirow[b]{2}{*}{ No } & \multirow[b]{2}{*}{ Parameter } & \multicolumn{3}{|c|}{ Stasiun } \\
\hline & & $\begin{array}{c}1 \\
\text { Dulamayo Selatan } \\
\left(\mathbf{N . 0}{ }^{\circ} 41^{\prime} 17,484\right)\end{array}$ & $\begin{array}{c}\text { II } \\
\text { Longalo } \\
\left(\mathbf{N . 0} 40^{\prime} 236604\right)\end{array}$ & $\begin{array}{c}\text { III } \\
\text { Boidu } \\
\left(\mathrm{N} .0^{0} 38^{\prime} 1,2876\right)\end{array}$ \\
\hline 1. & Suhu & $25^{0} \mathrm{C}$ & $26^{0} \mathrm{C}$ & $28^{0} \mathrm{C}$ \\
\hline 2. & Salinitas air & $0,1 \mathrm{ppt}$ & $0,1 \mathrm{ppt}$ & $0,1 \mathrm{ppt}$ \\
\hline 3. & $\overline{\mathrm{DO}}$ & $0,07 \mathrm{mg} / 1$ & $0,07 \mathrm{mg} / 1$ & $0,05 \mathrm{mg} / 1$ \\
\hline 4. & $\mathrm{pH}$ air & 7 & 7 & 5 \\
\hline 5. & Kecerahan air & $14 \mathrm{~cm}$ & $10 \mathrm{~cm}$ & $7 \mathrm{~cm}$ \\
\hline & Kecepatan arus & $0,4 \mathrm{~m} / \mathrm{s}$ & $0,6 \mathrm{~m} / \mathrm{s}$ & $1,6 \mathrm{~m} / \mathrm{s}$ \\
\hline
\end{tabular}

Untuk lebih jelasnya hasil identifikasi mikroalga dari perairan sungai Bulango dapat diuraikan sebagai berikut:

\section{Oscilatoria $s p$}

Berdasarkan hasil identifikasi Oscilatoria sp secara morfologi berbentuk lurus dan panjang, memiliki pigmen warna hijau, memiliki dinding sel, dinding sel tebal dan berwarna kuning, pada pengamatan ujung filamen berbentuk bulat, memiliki warna hijau tebal bergaris-garis (Gambar 1).

Hasil identifikasi Oscilatoria sp dengan menggunakan buku identifikasi karangan Serediak \& Mailinh (2011), yaitu: 1b, 2a, 3a, 4a, 5b, 6a, 9a yakni organisme mikroskopis, sel dikelompokkan bersama untuk membentuk filament untai atau pita, warna saat segar sering biru-hijau tetapi lebih 
banyak hijau zaitun, filamen atau trikoma tanpa percabangan, trikoma tidak membentuk spiral yang teratur, dapat bergerak, filamen dalam koloni dapat bergeser kedepan dan kebelakang.

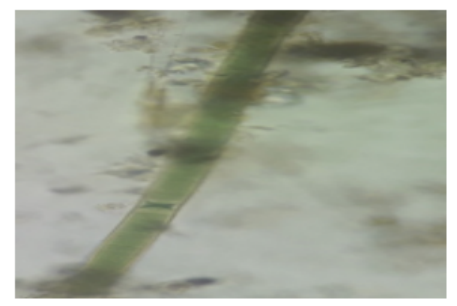

Gambar 1. Oscilatoria sp (Perbesaran 40x10) (Sumber: Dokumentasi pribadi, 2018)

Berdasarkan uraian di atas maka klasifikasi jenis mikroalga ini adalah sebagai berikut (Wijoyono dkk, 2013).

$\begin{array}{ll}\text { Kingdom } & \text { : Plantae } \\ \text { Divisi } & \text { : Cynophyta } \\ \text { Kelas } & \text { : Cynaphyceae } \\ \text { Ordo } & \text { : Oscillatoriales } \\ \text { Famili } & \text { : Oscilatoriaceae } \\ \text { Genus } & \text { : Oscilatoria } \\ \text { Species } & \text { : Oscilatoria } s p\end{array}$

\section{Melosira sp}

Berdasarkan hasil identifikasi Melosira sp secara morfologi memiliki sel empat persegi panjang atau bulat telur, sel bergabung bersama untuk membentuk filamen, memiliki dinding sel persegi panjang dan tebal. Kloroplas berwarna hijau pucat (Gambar 2).

Hasil identifikasi Melosira sp dengan menggunakan buku identifikasi karangan Serediak \& mailinh (2011), yaitu: 1b, 2a, 3a, 4a, 12a, 13a, yakni organisme mikroskopis, Sel dikelompokkan bersama untuk membentuk filament untai atau pita, kadang-kadang filamen dapat tumbuh dan terlihat secara massal, kloroplas memiliki warna saat segar mungkin rumput hijau, hijau pucat, emas coklat, hijau zaitun atau (jarang) kebiruan atau kemerahan, sel bergabung bersama untuk membentuk filamen terus menerus, dinding sel tanpa tanda jelas (Serediak dan Mailinh, 2011).

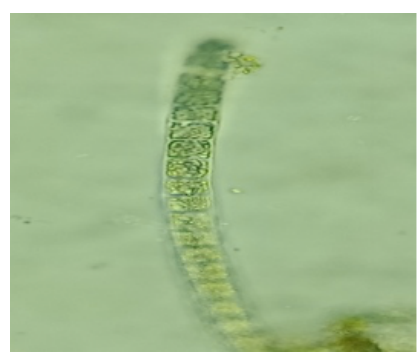

Gambar 2. Melosira sp (Perbesaran 40x10) (Sumber: Dokumentasi pribadi, 2018)

Berdasarkan uraian di atas maka klasifikasi jenis mikroalga ini adalah sebagai berikut (Wirosaputro, 1990).

$\begin{array}{ll}\text { Kingdom } & \text { : Plantae } \\ \text { Division } & : \text { Chrysophyta } \\ \text { Class } & \text { : Bacillariophyceae } \\ \text { Order } & : \text { Coscinodiscophycidae } \\ \text { Family } & : \text { Melosirales } \\ \text { Genus } & : \text { Melosira } \\ \text { Species } & : \text { Melosira } s p\end{array}$

\section{Navicula sp}

Berdasarkan hasil identifikasi Navicula sp secara morfologi memiliki katup lanset, sel seringkali sangat motil, bagian pinggirnya bergerigi (Gambar 3).

Hasil identifikasi Navicula sp dengan menggunakan buku identifikasi karangan Serediak \& 
mailinh (2011), yaitu: 1b, 2b, 17a, 22a,23a, 24b, 25a yakni Organisme mikroskopis, Sel individu atau dalam kelompok yang mungkin teratur atau tidak teratur dalam bentuk tetapi tidak membentuk filamen, untai atau pita, Pigmen sel Lokal di kloroplas, sel disusun dalam koloni bentuk yang pasti, Sel koloni tanpa flagella, sel sebagian besar soliter, Kedua ujung mengecil dan membulat, pergerakan yang lambat (Serediak dan Mailinh, 2011).

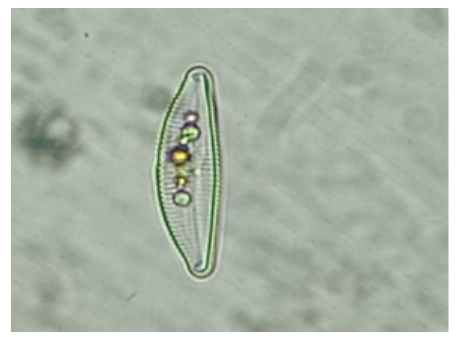

Gambar 3. Navicula sp (Perbesaran 40x10). (Sumber: Dokumentasi pribadi, 2018)

Berdasarkan uraian di atas maka klasifikasi jenis mikroalga ini adalah sebagai berikut (Wijoyono dkk, 2013)

$\begin{array}{ll}\text { Kingdom } & \text { : Plantae } \\ \text { Division } & \text { : Chrysophyta } \\ \text { Class } & \text { : Bacillariophyceae } \\ \text { Ordo } & \text { : Pennales } \\ \text { Famili } & \text { : Naviculaceae } \\ \text { Genus } & \text { : Navicula } \\ \text { Spesies } & : \text { Navicula } p\end{array}$

\section{Oedogonium sp}

Berdasarkan hasil identifikasi Oedogonium sp secara morfologi memiliki Sel bentuk panjang, tidak bercabang, memiliki dinding Sel. Beberapa sel di sepanjang filamen akan memiliki garis-garis melintang seperti cincin dan memiliki hijau pucat (Gambar 4).

Hasil identifikasi spesies Oedogonium sp dengan menggunakan buku identifikasi karangan Serediak \& mailinh (2011), yaitu: 1a, 2a, 3a, 4b, 13a, 14a, 15b, 16b yakni Organisme mikroskopis, Sel individu atau dalam kelompok dan tidak membentuk filamen, untai pita, warna saat segar mungkin rumput hijau, hijau pucat, emas coklat, hijau zaitun atau (jarang) kebiruan atau kemerahan, tidak terbuat dari silica, kloroplas tidak dalam bentuk sebuah band spiral, kloroplas reticular, dinding sel tidak tebal, silinder, kadang-kadang sedikit bengkak di salah satu ujun dan beberapa sel di sepanjang filamen akan memiliki garis-garis melintang cincin. (Serediak dan Mailinh, 2011).

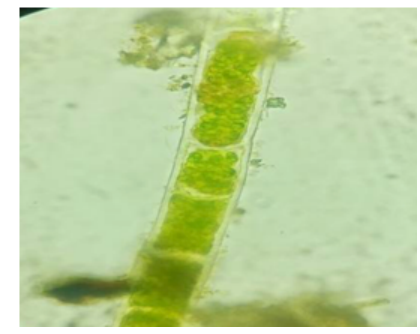

Gambar 4. Oedogonium sp (Perbesaran 40x10). (Sumber: Dokumentasi pribadi, 2018)

Berdasarkan uraian di atas maka klasifikasi jenis mikroalga ini adalah sebagai berikut (Wijoyono dkk, 2013).

$\begin{array}{ll}\text { Kingdom } & : \text { Plantae } \\ \text { Divisio } & : \text { Chlorophyta } \\ \text { Klas } & : \text { Chlorophyceae } \\ \text { Ordo } & : \text { Oedogoniales } \\ \text { Famili } & : \text { Oedoniaceae } \\ \text { Genus } & : \text { Oedogonium } \\ \text { Spesies } & : \text { Oedogonium sp }\end{array}$




\section{Gonium sp}

Berdasarkan hasil identifikasi Gonium sp secara morfologi memiliki sel dalam koloni, Kloroplas berwarna hijau dan berbentuk cawan (Gambar 5).

Hasil identifikasi spesies Gonium sp dengan menggunakan buku identifikasi karangan Serediak \& mailinh (2011), yaitu: 1b, 2b, 16a, 17b, 20a, 21b, yakni Organisme mikroskopis, sel individu atau dalam kelompok yang mungkin teratur atau tidak teratur dalam bentuk tetapi tidak membentuk filamen, untai atau pita, sel disusun dalam koloni bentuk yang pasti, koloni dengan lebih banyak sel dari 64 sampai 100, sel bulat telur (Serediak dan Mailinh, 2011).

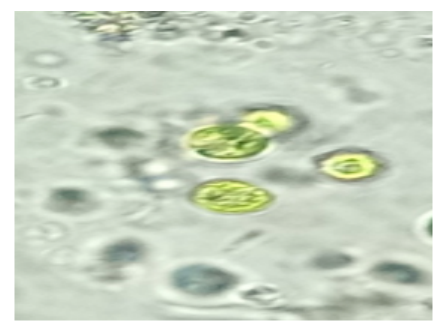

Gambar 5. Gonium sp (Perbesaran 40x10). (Sumber: Dokumentasi pribadi, 2018)

Berdasarkan uraian di atas maka klasifikasi jenis mikroalga ini adalah sebagai berikut (Wijoyono dkk, 2013).

$\begin{array}{ll}\text { Kingdom } & : \text { Plantae } \\ \text { Divisi } & : \text { Chlorophyta } \\ \text { Kelas } & : \text { Chlorophyceae } \\ \text { Ordo } & : \text { Volvocales } \\ \text { Famili } & : \text { Goniaceae } \\ \text { Genus } & : \text { Gonium } \\ \text { Spesies } & : \text { Gonium } s p\end{array}$

\section{Pembahasan}

Berdasarkan hasil identifikasi pada stasiun I bagian hulu desa Dulamayo Selatan dengan karateristik sungai yaitu berbatu, dangkal dan masih kurang aktifitas manusia karena pemukiman belum terlalu banyak, mikroalga epilitik yang diperoleh, yaitu Oscilatoria $s p$, Melosira sp, Navicula sp, Oedogonium $s p$ dan Gonium $s p$. Hal ini didukung oleh adanya faktor-faktor lingkungan yang menudukung pertumbuhan dari mikroalga epilitik itu sendiri. Hasil pengukuran factor lingkungan diperoleh bahwa tingkat kecerahan air $14 \mathrm{~cm}$, kecepatan arus rata-rata mencapai $0,4 \mathrm{~m} / \mathrm{s}$ dengan kondisi dasar perairan sebagian besar batu, kerikil dan sedikit pasir, memiliki $\mathrm{pH} 7$ yang masih berada pada nilai optimal untuk mikroalga epilitik, nilai DO yaitu $0,07 \mathrm{mg} / 1$ serta DO yaitu $0,07 \mathrm{mg} / 1 \mathrm{dan}$ suhu sekitar $25^{\circ} \mathrm{C}$. Menurut Rina (2012) bahwa tingkat suhu berkorelasi terhadap oksigen terlarut, sebab semakin tinggi suhu perairan, kelarutan oksigennya semakin menurun

Hasil identifikasi pada stasiun II yang berada di bagian tengah desa Longalo dengan karateristik sungai berbatu, berarus dan sudah ada aktifitas manusia di pinggiran sungai seperti menanaman jagung dan cabe bahkan sebagaian warga menggunakan sungai sebagai tempat mencuci kain, motor, mandi, dan membuang air besar ada 4 mikroalga epilitik yaitu Oscilatoria sp, Melosira sp, Navicula sp, Oedogonium $s p$ berbeda dengan stasiun I, pada stasiun II Gonium $s p$ tidak ditemukan. Hal ini dikarenakan kecerahan air pada stasiun II mulai menurun yaitu $10 \mathrm{~cm}$, meningkatnya kekeruhan pada stasiun II ini mengindikasikan telah terjadi pencemaran. Berbagai aktivitas manusia seperti mencuci hewan ternak, mencuci motor, mencuci pakaian di bantaran sungai telah memberi pengaruh pada kualitas sungai. Menurut Sastrawijaya (2000), adanya limbah yang masuk ke sungai, misalnya sampah organik (feses, kotoran hewan, pakan ikan, dan daun-daunan) dan anorganik (pestisida dan minyak pelumas dari traktor) merupakan benda asing bagi organisme yang ada di sungai. Setiap organisme mempunyai batas toleransi terhadap suatu faktor yang ada di lingkungannya. Kecepatan arus stasiun II berbeda dengan stasiun I, dimana pada stasiun II kecepatan arus lebih tinggi yaitu $0,6 \mathrm{~m} / \mathrm{s}$ kecepatan arus juga mempengaruhi keberadaan alga epilitik. Menurut Suin (2002) kecepatan arus dari suatu 
badan air ikut menentukan penyebaran organisme yang hidup di dalam air tersebut, sebagaimana dikatakan oleh Semiden dkk (2013), kecepatan arus yang rendah pada suatu perairan menyebabkan kelimpahan yang tinggi pada kelas Chlorophyceae karena kemungkinan terjadinya migrasi horizontal sangat tinggi.

Hasil identifikasi pada stasiun III yang berada di bagian hilir desa Boidu dengan karateristik sungai berpasir, arus kuat, dan sudah ada berbagai aktivitas pertanian dan penambangan pasir dan batu secara besar-besaran, ada 2 mikroalga yang ditemukan yaitu Melosira sp dan Navicula sp, hal ini dikarenakan pada stasiun III nilai $\mathrm{pH}$ air 5 berbeda dengan stasiun I dan stasiun II yang memilki nilai pH air 7, di mana menurut Simamora dkk (2012), sebagian besar biota akuatik sensitif terhadap perubahan $\mathrm{pH}$ dan menyukai nilai $\mathrm{pH}$ dengan kisaran 6-8. Derajat keasaman $(\mathrm{pH})$ merupakan pembatas kehidupan mikroalga, biota perairan tawar maupun laut sensitif terhadap perubahan $\mathrm{pH}$. Derajat keasaman dibawah 5 umumnya bersifat toksik dan mematikan sebagian besar biota perairan tawar. Menurut Siahaan dkk (2011), Perubahan $\mathrm{pH}$ menjadi hal yang peka bagi sebagian besar biota akuatik, organisme akuatik lebih menyukai $\mathrm{pH}$ mendekati $\mathrm{pH}$ netral.

Faktor lingkungan lainnya yaitu DO (Dessolved oxigen). DO pada stasiun III yaitu $0,05 \mathrm{mg} / 1$ berbeda dengan stasiun I dan stasiun II yaitu $0,07 \mathrm{mg} / 1$. Penyebab utama berkurangnya kadar oksigen terlarut dalam air disebabkan karena adanya zat pencemar yang dapat mengkonsumsi oksigen. Zat pencemar tersebut terutama terdiri dari bahan-bahan organik dan anorganik yang berasal dari barbagai sumber, seperti kotoran (hewan dan manusia), sampah organik, bahan-bahan buangan dari industri (pabrik tahu) dan rumah tangga.

Fitoplankton yang termasuk dalam kelas Bacillariophyceae ini mempunyai adaptasi yang tinggi dan ketahanan hidup pada berbagai kondisi perairan termasuk kondisi ekstrim. Menurut Odum (1998), banyaknya kelas Bacillariophyceae di perairan disebabkan oleh kemampuannya beradaptasi dengan lingkungan, tahan terhadap kondisi ekstrim serta mempunyai daya reproduksi yang tinggi. Adanya padatan terlarut yang tinggi akan menimbulkan kekeruhan yang dapat mengakibatkan menurunnya oksigen terlarut (Dissolved Oxygen/DO) dalam badan air, yang selanjutnya mengganggu suplai oksigen bagi organisme air termasuk mikroalga dimana kecerahan air pada stasiun III menurun yaitu 7 $\mathrm{cm}$ berbeda dengan stasiun I dan II. Menurut Sanita dkk (2011), bahwa penetrasi cahaya seringkali dihalangi oleh zat yang terlarut dalam air, membatasi zona fotosintesa dimana habitat akuatik dibatasi oleh kedalaman dan kekeruhan, terutama bila disebabkan oleh lumpur dan partikel yang dapat mengendap sering kali penting sebagai fakor pembatas kehidupan mikroalga, banyaknya padatan yang terlarut dalam air mengakibatkan menurunnya penetrasi cahaya matahari yang masuk ke dalam badan air, sehingga mengganggu proses fotosintesis tumbuhan air seperti ganggang air dan mikroalga.

Meningkatnya kekeruhan pada stasiun III ini mengindikasikan telah terjadi pencemaran. Berbagai aktivitas seperti pertanian dan penambangan pasir dan batu secara besar-besaran yang dapat mengganggu wilayah hilir pengambilan pasir maupun batu di area sungai memberi pengaruh pada ekosistem yang ada di sungai terutama biota yang hidup di dalamnya. Pada jarak 2-10 km di bagian sungai lokasi pengamatan ditemukan tempat pertanian dan penambangan pasir dan batu dalam skala besar, hal ini dapat mengubah kondisi lingkungan sungai dan ditemukan tanah seluas \pm 3 ha menjadi area pertanian jagung dan budi daya tanaman seperti sayuran dan rempah seperti rica. Menurut Nybakken (1992), kelas Bacillariophyceae mampu tumbuh dengan cepat meskipun pada kondisi nutrien dan cahaya yang rendah, hal ini juga dikarenakan kelas ini mampu meregenerasi dan reproduksi yang lebih besar dan juga memiliki kemampuan beradaptasi dengan baik. Faktor lingkungan lainnya yang mendukung kehidupan mikroalga yaitu kecepatan arus, kecepatan arus pada stasiun III 1,6 m/s. Kecepatan arus akan mempengaruhi berbagai faktor fisika, kimia, dan biologi perairan, termasuk penyebaran fitoplankton. Kecepatan arus berperan penting dalam penyebaran (distribusi) fitoplankton hal ini sesuai yang dikemukakan Adriansyah (2014) menyatakan kecepatan arus yang tinggi dapat mengurangi jenis organisme dan hanya jenis-jenis yang melekat kuat yang dapat hidup. Kecepatan arus berpengaruh pada kemampuan mikroalga epilitik untuk menempel pada suatu substrat. 
Kemampuan mikroalga beradaptasi adalah salah satu faktor yang dapat menjadi penentu kehidupan mikroalga. Seperti yang dikemukakan oleh Yayu (2012), bahwa kondisi air sungai dapat menjadi penentu adanya kemampuan mikroalga beradaptasi atau tidak. Selanjutnya menurut Rina (2012), Perairan yang tidak tercemar memiliki keanekaragaman biota yang tinggi, dengan jumlah jenis yang tinggi, sedangkan pada perairan yang tercemar memiliki keanekaragaman yang rendah bahkan tidak sama sekali.

\section{Kesimpulan}

Berdasarkan hasil penelitian di perairan sungai Bulango diperoleh 5 mikroalga epilitik pada perairan sungai Bulango yaitu Oscillatoria sp, Melosira sp, Oedogonium sp, Navicula sp, dan Gonium sp.

\section{References}

Andriansyah, T. R. Setyawati, Lovadi. 2014. Kualitas Perairan Kanal Sungai Jawi dan Sungai Raya Dalam Kota Pontianak Ditinjau dari Struktur Komunitas Mikroalga Perifitik. Universitas Tanjungpura. Jurnal Protobiont: Vol 3 (1) : 61 - 70

Ayeni, O.O., Ndakidemi, P.A., Snyman R.G., and Odendaal J.P. 2010. Chemical, Biological and Physiological Indicators of Metal Pollution in wetlands. Review. Scientific Research and Essays. Vol 5 (15): 1938-1949

Nybakken, J.M. 1992. Biologi Laut: Suatu Pendekatan Ekologis (diterjemahkan oleh H.M. Eidmar, Koesoebiono, D.G. Bengen, M. Hutomo dan D. Sukardjo). Gramedia. Jakarta.

Odum, E.P. 1998. Dasar-dasar Ekologi (Fundamentals of Ecology). Diterjemahkan oleh Tj. Samingan. Gajah Mada University Press, Yogyakarta.

Rina P. A, Philip, dan Sumiarsa. 2012. Kelimpahan Beberapa Jenis Mikroalga Diatom Di Perairan Pulau Gumilamo-Magaliho, Halmahera Utara. Jurnal Ilmu dan Teknologi Kelautan Tropis, Vol. 4, No.

Sanita, T.H, Bambang S, Marsoedi. 2001. Penentuan Status Kualitas Perairan Sungai Brantas Hulu Dengan Biomonitoring Makrozoobentos: Tinjauan Dari Pencemaran Bahan Organik. Universitas Brawijaya Malang. Jurnal Biosain Vol. 1, No.1

Sanjaya, W. 2008. Strategi pembelajaran berorientasi standar proses pendidikan. Jakarta: kencana prenada media groug.

Sastrawijaya. 2000. Pencemaran Lingkungan Jakarta. Jakarta: Rineka Cipta.

Serediak \& Mailinh. 2011. Alga identification Lab Guide. Agriculture and Agri Food Canada. Canada.

Simamora, Achmad., dan Inayah. 2012. Kualitas Air Sungai Bone (Gorontalo) Berdasarkan Bioindikator Makroinvertebrata. Gorontalo.

Soewarno, 1991. Hidrologi: Pengukuran dan Pengolahan Data Aliran Sungai. Penerbit NOVA, Bandung.

Suin, N. M. 2002. Metoda Ekologi. Universitas Andalas : Padang.

Yayu, Tontowi, R. Sukmawati. 2010. Penelitian Pengolahan Air Sungai Yang Tercemar Oleh Bahan Organik. Pusat Linbag Sumber Daya Air. Bandung. Oktober 2010.

Zhou Q., Zhang J., Fu J., Shi J., Jiang G. 2008. Biomonitoring: An Appealing Tool for Assessment of Metal Pollution in the Aquatic Ecosystem. Review. Elsevier. 